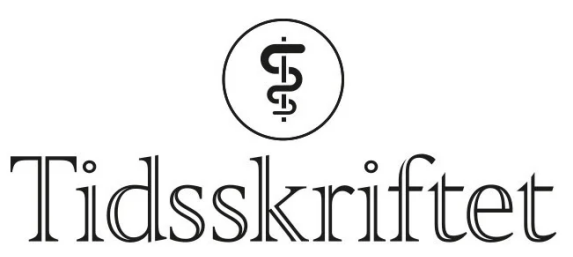

DEN NORSKE LEGEFORENING

\title{
Underliggende tilstander hos voksne med covid-19
}

ORIGINALARTIKKEL

\section{WENCHE NYSTAD}

wenche.nystad@fhi.no

Avdeling for kroniske sykdommer og aldring

Folkehelseinstituttet

Hun har bidratt med idé, design, kvalitetssikring og tolking av resultater, utarbeiding og revisjon av manuset og har godkjent innsendte manusversjon.

Wenche Nystad er ph.d., epidemiolog og seniorforsker.

Forfatteren har fylt ut ICMJE-skjemaet og oppgir ingen interessekonflikter.

\section{VIDAR HJELLVIK}

Avdeling for kroniske sykdommer og aldring

Folkehelseinstituttet

Han har bidratt med kvalitetssikring av statistikk, analyser, fremstilling og tolking av resultater, utarbeiding og revisjon av manuset og har godkjent innsendte manusversjon.

Vidar Hjellvik er dr.scient., statistiker og seniorforsker.

Forfatteren har fylt ut ICMJE-skjemaet og oppgir ingen interessekonflikter.

\section{INGER KRISTIN LARSEN}

Registeravdelingen

Kreftregisteret

Hun har bidratt med idé, design, kvalitetssikring og tolking av resultater, utarbeiding og revisjon av manuset og har godkjent innsendte manusversjon.

Inger Kristin Larsen er ph.d., epidemiolog og forsker.

Forfatteren har fylt ut ICMJE-skjemaet og oppgir ingen interessekonflikter.

\section{INGER ARIANSEN}

Avdeling for kroniske sykdommer og aldring

Folkehelseinstituttet

Hun har bidratt med kvalitetssikring og tolking av resultater, utarbeiding og revisjon av manuset og har godkjent innsendte manusversjon.

Inger Ariansen er ph.d., lege og seniorforsker.

Forfatteren har fylt ut ICMJE-skjemaet og oppgir ingen interessekonflikter.

\section{EYVIND HELLAND}

Avdeling for helseregistre

Helsedirektoratet

Trondheim

Han har bidratt med kvalitetssikring av tilrettelegging av statistikk og analyser, tolking av resultater, utarbeiding og revisjon av manuset og har godkjent innsendte manusversjon. 
Eyvind Helland er ph.d.-student i psykologi ved NTNU og rådgiver.

Forfatteren har fylt ut ICMJE-skjemaet og oppgir ingen interessekonflikter.

\section{KNUT IVAR JOHANSEN}

Avdeling for helseregistre

Helsedirektoratet

Trondheim

Han har bidratt med tolking av resultater, utarbeiding og revisjon av manuset og har godkjent innsendte manusversjon.

Knut Ivar Johansen er cand.polit. i sosiologi og seksjonssjef.

Forfatteren har fylt ut ICMJE-skjemaet og oppgir ingen interessekonflikter.

\section{JOHANNE GULBRANDSEN}

Dataflytseksjonen

Registeravdelingen

Kreftregisteret

Hun har bidratt med tolking av resultater, utarbeiding og revisjon av manuset og har godkjent innsendte manusversjon.

Johanne Gulbrandsen er helseinformatiker og seksjonsleder.

Forfatteren har fylt ut ICMJE-skjemaet og oppgir ingen interessekonflikter.

\section{HANNE LØVDAL GULSETH}

Avdeling for kroniske sykdommer og aldring

Folkehelseinstituttet

Hun har bidratt med idé, tolking av resultater, utarbeiding og revisjon av manuset og har godkjent innsendte manusversjon.

Hanne Løvdal Gulseth er ph.d., lege og avdelingsdirektør.

Forfatteren har fylt ut ICMJE-skjemaet og oppgir ingen interessekonflikter.

\section{HELENA NIEMI EIDE}

Avdeling for smittevern og beredskap

Folkehelseinstituttet

Hun har bidratt med tolking av resultater, utarbeiding og revisjon av manuset og har godkjent innsendte manusversjon.

Helena Niemi Eide er MPH og lege.

Forfatteren har fylt ut ICMJE-skjemaet og oppgir ingen interessekonflikter.

\section{SIRI E. HÅBER}

Senter for fruktbarhet og helse

Folkehelseinstituttet

Hun har bidratt med idé, design, tolking av resultater, utarbeiding og revisjon av manuset og har godkjent innsendte manusversjon.

Siri E. Håberg er ph.d., lege og seniorforsker.

Forfatteren har fylt ut ICMJE-skjemaet og oppgir ingen interessekonflikter.

\section{ØYSTEIN KARLSTAD}

Avdeling for kroniske sykdommer og aldring

Folkehelseinstituttet

Han har bidratt med design, fremstilling og tolking av resultater, utarbeiding og revisjon av manuset og har godkjent innsendte manusversjon.

Øystein Karlstad er ph.d., farmasøyt og seniorforsker.

Forfatteren har fylt ut ICMJE-skjemaet og oppgir ingen interessekonflikter.

\section{INGER JOHANNE BAKKEN}

Avdeling for helseregistre

Helsedirektoratet

Trondheim

Hun har bidratt med idé, design, tilrettelegging av statistikk, dataanalyse, tolking av resultater, utarbeiding og revisjon av manuset og har godkjent innsendte manusversjon.

Inger Johanne Bakken er dr.ing. og seniorrådgiver. 


\section{BAKGRUNN}

Hjerte- og karsykdommer, kreft, type 2-diabetes og kronisk obstruktiv lungesykdom (kols) ble tidlig nevnt som de vanligste sykdommene blant personer innlagt på sykehus for covid19. Kunnskapsgrunnlaget er imidlertid svakt. Hensikten med denne studien er å beskrive hvordan utvalgte sykdomstilstander fordeler seg blant voksne med påvist covid-19 (covid19-testpositive) og blant innlagte (covid-19-innlagte) sammenlignet med befolkningen.

\section{MATERIALE OG METODE}

Vi benyttet data fra Norsk pasientregister, Kommunalt pasient- og brukerregister og Meldingssystem for smittsomme sykdommer for voksne fra fylte 20 år for perioden 1.3.2020-13.5.2020.

\section{RESULTATER}

Av alle covid-19-testpositive var 7632 (94\%) 20 år og eldre, og 1025 (13,4\%) av disse hadde vært innlagt på sykehus. Blant covid-19-innlagte var det flere med hjerte- og karsykdommer ( $18,3 \%$ versus $15,6 \%$ ), $\operatorname{kreft}(6,9 \%$ versus $5,4 \%$ ), type 2 -diabetes ( $8,6 \%$ versus $5,2 \%$ ) og kols (3,8 \% versus 2,7 \%) enn i befolkningen etter aldersjustering. Andelen innlagte med astma, annen kronisk lungesykdom, hjerte- og karsykdommer, kreft under behandling, komplikasjoner til hypertensjon, fedme og overvekt, nevrologiske lidelser og hjerte- og nyresvikt var også høyere enn i befolkningen. Det var liten forskjell i forekomst av sykdomstilstandene mellom covid-19-testpositive og befolkningen.

\section{FORTOLKNING}

Blant covid-19-innlagte var det flere med underliggende sykdomstilstander enn i befolkningen. Det kan bety at disse får et mer alvorlig sykdomsforl øp eller at de hyppigere legges inn enn ellers friske personer. Resultatene må tolkes med forsiktighet, fordi utvalget av covid-19-pasienter er selektert.

\section{HOVEDFUNN}

Av alle covid-19-testpositive var 7632 (94\%) 20 år og eldre, og 1025 (13,4\%) av disse hadde vært innlagt på sykehus.

Blant covid-19-innlagte var det flere med ulike underliggende sykdomstilstander enn i befolkningen etter aldersjustering.

Mellom covid-19-testpositive og befolkningen var det liten forskjell i forekomst av underliggende sykdomstilstander.

Covid-19 skyldes infeksjon med SARS-CoV-2 (severe acute respiratory syndrome coronavirus 2), og dette koronaviruset spredte seg raskt til en global pandemi etter at det første tilfellet ble rapportert i Wuhan i desember 2019. Ikke-smittsomme sykdommer som hjerte- og karsykdommer, kreft, diabetes og kroniske lungesykdommer ble tidlig nevnt som de vanligste sykdommene hos personer som ble innlagt på sykehus for covid-19 (1). I starten av utbruddet ble også høy alder utpekt som en viktig risikofaktor for alvorlig forløp $(\underline{2}, 3)$. Sykdomsbildet ved covid-19 spenner bredt. Noen vil ikke merke symptomene, mens et mindretall vil få alvorlig forløp med lungebetennelse og behov for sykehusinnleggelse og eventuelt intensivbehandling. 
Yngre har oftere mildere forløp enn eldre og legges sjeldnere inn på sykehus for covid-19 (4). Det har vært diskutert om kroniske sykdommer uavhengig øker risikoen for alvorlig forløp, eller om tilstedeværelsen av slike sykdommer reflekterer at det er flere eldre blant dem som får alvorlig sykdom (4). Testkapasiteten i Norge har vært begrenset, og man har vært særlig årvåken overfor personer med underliggende sykdommer. Disse kan dermed være overrepresentert blant dem som blir testet for covid-19. Vi vet fremdeles lite om hvor stor betydning ulike sykdomstilstander, alder og kjønn kan ha for alvorlig forløp ved covid19-infeksjon. Hensikten med denne studien er å beskrive hvordan ulike sykdomstilstander fordeler seg blant personer med påvist smitte av covid-19 og blant innlagte med covid-19 sammenlignet med tilsvarende tall for befolkningen.

\section{Materiale og metode}

I denne studien har vi benyttet data fra Norsk pasientregister (NPR), Kommunalt pasientog brukerregister (KPR) (5), Meldingssystem for smittsomme sykdommer (MSIS) ved Folkehelseinstituttet og Personregisteret (Norsk Helsenetts versjon av Folkeregisteret).

Norsk pasientregister er en administrativ database som inneholder aktivitetsdata fra alle offentlig finansierte sykehus og poliklinikker fra 2008. Rapportering til registeret er obligatorisk og danner grunnlaget for refusjoner i spesialisthelsetjenesten. Registeret inneholder identitet og ICD-10-koder (International Classification of Diseases, 10th revision). Kommunalt pasient- og brukerregister, opprettet i 2016, omfatter blant annet refusjonskrav fra behandlere i primærhelsetjenesten som rettes til den statlige forvaltningen. For refusjonskrav benyttes kodesystemet ICPC-2 (International Classification for Primary Care, 2nd edition). Meldingssystem for smittsomme sykdommer mottar fortløpende melding fra mikrobiologiske laboratorier om påvist infeksjon med SARS-CoV-2. Personregisteret ble brukt til å avgrense utvalget til personer som var i live og ikke hadde emigrert per 1.3.2020.

Helsedirektoratet fikk utlevert MSIS-data om alle individer som hadde testet positivt for SARS-CoV-2 ved polymerasekjedereaksjonstest (PCR) i perioden 1.3.2020-13.5.2020. MSISdataene ble sammenstilt med data fra Norsk pasientregister og Kommunalt pasient- og brukerregister ved hjelp av et felles prosjektspesifikt løpenummer for de tre registrene. Uttrekk og koblinger av data og tilrettelegginger av statistikk er gjennomført ved hjelp av databaseverktøyet SQL Server Management Studio (SSMS, Microsoft) og statistikkverktøyet $\mathrm{R}(\underline{6})$.

Befolkningsdata ble hentet fra nettsidene til Statistisk sentralbyrå (befolkningsstatistikk per 1.1.2020 fra fylte 20 år).

ETIKK

Tilretteleggingene av statistikk er hjemlet i forskriftene for registrene, ettersom formålet med denne studien var overvåking og beredskap. Medarbeidere ved Helsedirektoratet hadde ikke tilgang til fødselsnummer eller andre direkte personidentifiserende kjennetegn. Medarbeiderne i Folkehelseinstituttet fikk kun tilgang til aggregerte data i form av tabeller.

\section{DEFINISJONER}

Sykdommer og tilstander som kunne gi $ø$ kt risiko for alvorlig forløp av covid-19 ble definert med bakgrunn i kunnskap om covid-19-forløp fra andre land, smitterisiko for influensa og sykdommers forløp samt behandling og mulige effekter på immunsystemet $(\underline{2})$. For noen kroniske sykdommer benyttet vi alle tilgjengelige data tilbake i tid, mens vi for andre gikk syv eller fem år tilbake i tid avhengig av kunnskap om sykdomsforl $\emptyset \mathrm{p}$ (tabell 1, tabell 2). Vi inkluderte en lang rekke sykdommer, fordi beredskap og overvåking var hovedformålet med prosjektet og kunnskapen om covid-19 var lav. Kreftpasienter i aktiv behandling ble 
inkludert som en separat gruppe, fordi mange kreftpasienter fortsatt går til kontroll etter at de har blitt friske av kreftsykdommen og derfor er registrert i Norsk pasientregister med en diagnosekode for kreft.

\section{Tabell 1}

Definisjoner av sykdommer og tilstander benyttet i studien

\begin{tabular}{|c|c|c|}
\hline Sykdom/tilstand & ICD-10 & ICPC-2 \\
\hline Diabetes $^{1}$ & E10, E11 & T89, T90 \\
\hline Diabetes type $1^{1}$ & E10 & T89 \\
\hline Diabetes type $2^{1}$ & E11 & T90 \\
\hline Astma ${ }^{1}$ & $\mathrm{~J} 45, \mathrm{~J} 46$ & R96 \\
\hline $\begin{array}{l}\text { Kronisk obstruktiv } \\
\text { lungesykdom fra } 40 \text { år }^{1}\end{array}$ & $\mathrm{~J} 43, \mathrm{~J} 44$ & R95 \\
\hline $\begin{array}{l}\text { Annen kronisk } \\
\text { lungesykdom }\end{array}$ & $J 41, J 42, J 47, J 84, J 98$ & \\
\hline Kreft $^{2}$ & $\begin{array}{l}\text { C00-C97, D32-33, D35.2-35.4, D42-43, D44.3- } \\
44.5, \text { D45-47 }\end{array}$ & \\
\hline $\begin{array}{l}\text { Hjerte- og } \\
\text { karsykdommer }\end{array}$ & I00-199, G45, H34 & $\begin{array}{l}\text { K74-80, K82-83, } \\
\text { K85-87, K89-92 }\end{array}$ \\
\hline Hjerneslag $^{3}$ & G45, I60-161, I63-I64 (unntatt I63.6), 169 & К89, К90-К91 \\
\hline $\begin{array}{l}\text { Iskemisk } \\
\text { hjertesykdom }\end{array}$ & $120-125$ & K76 \\
\hline Atrieflimmer $^{3}$ & 148 & K78 \\
\hline Hjertesvikt $^{3}$ & $150,111.0,113.0,113.2,142$ & K77 \\
\hline Hypertensjon ${ }^{2}$ & 110 & K86 \\
\hline $\begin{array}{l}\text { Komplikasjoner til } \\
\text { hypertensjon }{ }^{2}\end{array}$ & $|11-| 13, \mid 15$ & K87 \\
\hline Fedme $^{2}$ & E66 & T82 \\
\hline Overvekt $^{2}$ & & T83 \\
\hline Hyperkolesterolemi $^{2}$ & E78 & T96 \\
\hline Demens $^{1}$ & F00-F03, G30, G31.0, G31.8, G31.2 & \\
\hline Hoftebrudd $^{1}$ & $\mathrm{~S} 72.0, \mathrm{~S} 72.1, \mathrm{~S} 72.2$ & \\
\hline Nyresvikt $^{1}$ & N18.3-N18.5 & \\
\hline $\begin{array}{l}\text { Magesår og } \\
\text { gallelidelser }^{2}\end{array}$ & K80, K81, K83, K25, K26, K27 & \\
\hline Nevrologiske lidelser ${ }^{1}$ & G12, G20-21, G30-32, G35, G40-41, G70-73 & \\
\hline Cerebral parese $^{1}$ & G80-G83 & \\
\hline Transplantasjon ${ }^{1}$ & Z94.0-Z94.4, Z94.8 & \\
\hline Immunsvikt ${ }^{1}$ & D80-D84 & \\
\hline
\end{tabular}




\begin{tabular}{|lll|}
\hline Sykdom/tilstand & ICD-10 & ICPC-2 \\
\hline $\begin{array}{l}\text { Revmatologiske } \\
\text { sykdommer }\end{array}$ & M05-M09 & L88 \\
\hline $\begin{array}{l}\text { Inflammatorisk } \\
\text { tarmsykdom }^{1}\end{array}$ & K50, K51, K52 & D94 \\
\hline Biologiske legemidler $^{4}$ & $\begin{array}{l}\text { 4AA23, 4AA24, 4AA26, 4AA33, 4AA34, 4AB02, } \\
\text { 4AB06, 4AC07 }\end{array}$ & P15-P16 \\
\hline Alkoholrelatert sykdom $^{1}$ & $\begin{array}{l}\text { F10, G62.1, G72.1, 142.6, K29.2, K70.0-K70.4, } \\
\text { K70.9, K86.0, O35.4, P04.3, Q86.0 }\end{array}$ & P18-P19 \\
\hline Annen rusdiagnose & F11-F19 & P72-P73, P98 \\
\hline Alvorlig psykisk lidelse $^{1}$ & F20-29, F30-31, F32.3, F33.3 & P01-P06, P74-85 \\
\hline Annen psykisk lidelse $^{1}$ & $\begin{array}{l}\text { F32 (unntatt F32.3), F33 (unntatt F33.3), F34- } \\
\text { F39, F40-F48 }\end{array}$ & \\
\hline
\end{tabular}

${ }^{1}$ Alle tilgjengelige historiske data i perioden 2008-19 i Norsk pasientregister (ICD10-koder) og juli 2016-mars 2020 i Kommunalt pasient- og brukerregister (ICPC2- koder) så langt man kan tilbake i tid

${ }^{2}$ Siste fem år

${ }^{3}$ Siste syv år

${ }^{4}$ Biologiske legemidler administrert i sykehus identifisert fra prosedyrekoder i Norsk pasientregister (brukes ved bl.a. multippel sklerose, revmatologiske sykdommer, ulcerøs kolitt, Crohns sykdom, psoriasis, spondylitt)

\section{Tabell 2}

Definisjoner av sykdommer og tilstander og andelen av disse i befolkningen 20 år og eldre, blant covid-19-testpositive og blant covid-19-innlagte. Antall og andel i prosent. For covid19-gruppene er andelene aldersjustert og vist med 95\% konfidensintervall.

\begin{tabular}{|c|c|c|c|}
\hline Sykdom/tilstand & $\begin{array}{l}\text { Befolkningen } \\
(\mathrm{N}=4118 \text { 831) } \\
\mathbf{n}(\%)\end{array}$ & $\begin{array}{l}\text { Covid-19- } \\
\text { testpositive } \\
(\mathrm{N}=7632) \\
\mathbf{n}(\%[95 \% \mathrm{KI}])\end{array}$ & $\begin{array}{l}\text { Covid-19- } \\
\text { innlagte } \\
(\mathrm{N}=1 \mathrm{O} 25) \\
\mathbf{n}(\%[95 \% \mathrm{KI}])\end{array}$ \\
\hline Diabetes $^{1}$ & $242592(5,9)$ & $468(6,3[5,8-6,9])$ & $\begin{array}{r}157(9,4[8,0- \\
11,0])\end{array}$ \\
\hline Diabetes type $1^{1}$ & $30007(0,7)$ & $44(0,6[0,4-0,8])$ & $7(0,6[0,3-1,3])$ \\
\hline Diabetes type $2^{1}$ & $212585(5,2)$ & $424(5,7[5,2-6.3])$ & $\begin{array}{r}150(8,6[7,3- \\
10,1])\end{array}$ \\
\hline Astma $^{1}$ & $225169(5,5)$ & $515(6,8[6,3-7,5])$ & $\begin{array}{r}127(11,5[9,7- \\
13,7])\end{array}$ \\
\hline $\begin{array}{l}\text { Kronisk obstruktiv lungesykdom } \\
\text { fra } 40 \mathrm{år}^{1}\end{array}$ & $111493(2,7)$ & $161(2,3[2,0-2,7])$ & $67(3,8[3,0-4,8])$ \\
\hline Annen kronisk lungesykdom ${ }^{1}$ & $13554(0,3)$ & $34(0,5[0,3-0,7])$ & $13(0,8[0,5-1,4])$ \\
\hline Kreft $^{2}$ & $224018(5,4)$ & $421(5,8[5,2-6,3])$ & $127(6,9[5,8-8,3])$ \\
\hline behandlet siste $6 \mathrm{md}$ & $23277(0,6)$ & $40(0,6[0,4-0,8])$ & $16(1,0[0,6-1,6])$ \\
\hline
\end{tabular}




\begin{tabular}{|c|c|c|c|}
\hline Sykdom/tilstand & $\begin{array}{l}\text { Befolkningen } \\
(\mathrm{N}=4118831) \\
\mathbf{n}(\%)\end{array}$ & $\begin{array}{l}\text { Covid-19- } \\
\text { testpositive } \\
(\mathrm{N}=7632) \\
\mathbf{n}(\%[95 \% \mathrm{KI}])\end{array}$ & $\begin{array}{l}\text { Covid-19- } \\
\text { innlagte } \\
(\mathrm{N}=1025) \\
\mathbf{n}(\%[95 \% \mathrm{KI}])\end{array}$ \\
\hline behandlet siste $3 \mathrm{md}$ & $10599(0,3)$ & $20(0,3[0,2-0,4])$ & $11(0,7[0,4-1,3])$ \\
\hline Hjerte- og karsykdommer ${ }^{3}$ & $644443(15,6)$ & $\begin{array}{r}1233(16,4[15,5- \\
17,4])\end{array}$ & $\begin{array}{r}333(18,3[16,4- \\
20,3])\end{array}$ \\
\hline Hjerneslag ${ }^{3}$ & $94766(2,3)$ & $190(2,5[2,2-2,9])$ & $49(2,4[1,8-3,2])$ \\
\hline Iskemisk hjertesykdom ${ }^{3}$ & $159355(3,9)$ & $278(3,7[3,3-4,2])$ & $94(4,5[3,7-5,5])$ \\
\hline Atrieflimmer ${ }^{3}$ & $132491(3,2)$ & $270(3,5[3,1-3,9])$ & $91(3,9[3,2-4,8])$ \\
\hline Hjertesvikt $^{3}$ & $63552(1,5)$ & $136(1,7[1,4-2,0])$ & $60(2,6[2,0-3,3])$ \\
\hline Hypertensjon ${ }^{2}$ & $578867(14,1)$ & $977(13,4[12,5-14,2])$ & $\begin{array}{r}251(14,4[12,7- \\
16,3])\end{array}$ \\
\hline $\begin{array}{l}\text { Komplikasjoner til } \\
\text { hypertensjon }^{2}\end{array}$ & $43419(1,1)$ & $88(1,2[1,0-1,5])$ & $32(1,6[1,2-2,3])$ \\
\hline Fedme $^{2}$ & $68047(1,7)$ & $120(1,5[1,3-1,8])$ & $26(2,8[1,9-4,2])$ \\
\hline Overvekt $^{2}$ & $56781(1,4)$ & $105(1,3[1,1-1,6])$ & $24(2,6[1,8-3,9])$ \\
\hline Hyperkolesterolemi & $28756(0,7)$ & $64(0,9[0,7-1,1])$ & $11(0,7[0,4-1,3])$ \\
\hline Demens $^{1}$ & $15190(0,4)$ & $107(1,3[1,1-1,6])$ & $9(0,4[0,2-0,7])$ \\
\hline Hoftebrudd ${ }^{1}$ & $7659(0,2)$ & $19(0,2[0,1-0,4])$ & $6(0,2[0,1-0,6])$ \\
\hline Nyresvikt $^{1}$ & $23196(0,6)$ & $67(0,9[0,7-1,1])$ & $37(1,7[1,3-2,4])$ \\
\hline Magesår og gallelidelser ${ }^{2}$ & $41846(1,0)$ & $88(1,1[0,9-1,4])$ & $21(1,5[1,0-2,4])$ \\
\hline Nevrologiske lidelser ${ }^{1}$ & $73178(1,8)$ & $197(2,6[2,3-3,0])$ & $42(3,0[2,2-4,0])$ \\
\hline Cerebral parese $^{1}$ & $10204(0,2)$ & $13(0,2[0,1-0,3])$ & $5(0,5[0,2-1,1])$ \\
\hline Transplantasjon $^{1}$ & $6921(0,2)$ & $22(0,3[0,2-0,4])$ & $12(0,9[0,5-1,6])$ \\
\hline Immunsvikt $^{1}$ & $3054(0,1)$ & $17(0,2[0,1-0,4])$ & $8(0,7[0,4-1,5])$ \\
\hline Revmatologiske sykdommer ${ }^{1}$ & $86720(2,1)$ & $157(2,1[1,8-2,5])$ & $35(2,5[1,8-3,5])$ \\
\hline Inflammatorisk tarmsykdom ${ }^{1}$ & $56206(1,4)$ & $95(1,3[1,0-1,5])$ & $22(2,0[1,3-3,0])$ \\
\hline Biologiske legemidler ${ }^{4}$ & $17849(0,4)$ & $24(0,3[0,2-0,5])$ & $6(0,6[0,3-1,4])$ \\
\hline Alkoholrelatert sykdom ${ }^{1}$ & $71592(1,7)$ & $79(1,0[0,8-1,3])$ & $11(1,0[0,6-1,9])$ \\
\hline Annen rusdiagnose ${ }^{1}$ & $69574(1,7)$ & $72(0,9[0,8-1,2])$ & $15(2,0[1,2-3,4])$ \\
\hline Alvorlig psykisk lidelse ${ }^{1}$ & $79363(1,9)$ & $91(1,2[1,0-1,4])$ & $17(1,8[1,1-2,9])$ \\
\hline Annen psykisk lidelse ${ }^{1}$ & $1070244(26,0)$ & $\begin{array}{r}1827(23,6[22,5- \\
24,7])\end{array}$ & $\begin{array}{r}259(27,0[23,9- \\
30,5])\end{array}$ \\
\hline
\end{tabular}

${ }^{1}$ Alle tilgjengelige historiske data i perioden 2008-19 i Norsk pasientregister (ICD1o-koder) og juli 2016-mars 2020 i Kommunalt pasient- og brukerregister (ICPC2-koder) så langt man kan tilbake i tid

${ }^{2}$ Siste fem år 
35iste syv år

${ }^{4}$ Biologiske legemidler administrert i sykehus identifisert fra prosedyrekoder i Norsk pasientregister (brukes ved bl.a. multippel sklerose, revmatologiske sykdommer, ulcerøs kolitt, Crohns sykdom, psoriasis, spondylitt)

For å definere sykdomstilstander benyttet vi data fra Norsk pasientregister for perioden 2008-19 (ICD-10-koder; hoved- og bidiagnoser) og fra Kommunalt pasient- og brukerregister (ICPC-2-koder) for perioden juli 2016-mars 2020 (tabell 1). For hver person registrert med minst én kontakt med en eller flere av disse tilstandene som hoved- eller bidiagnose og som ikke var døde eller hadde emigrert per 1.3.2020, ble det tilrettelagt dummyvariabler (ja/nei) for hver av sykdomstilstandene.

Informasjon om innleggelser for covid-19 er basert på data om avsluttede sykehusopphold som rapporteres månedlig til Norsk pasientregister (perioden januar-april 2020).

Periodene er noe ulike på grunn av de nasjonale rutinene for å melde sykehusinnleggelser til Norsk pasientregister samt tilgjengeligheten av data i prosjektet. Vi definerte innleggelse for covid-19 som positiv prøve for covid-19 og sykehusopphold med diagnosekode Uo7.1 (Covid-19 med påvist virus), B34.2 (Coronavirusinfeksjon med uspesifisert lokalisasjon) eller B97.2 (Coronavirus som årsak til sykdommer klassifisert i andre kapitler).

\section{STATISTISKE ANALYSER}

Analysene omfatter alle personer 20 år og eldre i den totale befolkningen, blant alle som har testet positivt for covid-19 og blant alle som har vært lagt inn for covid-19.

Andelen personer som er registrert med hver sykdomstilstand i de tre populasjonene, blir beskrevet i prosent. Vi presenterer resultater for alle sykdomstilstandene for menn og kvinner samlet og fordelt på 2o-årsaldersgrupper (20-39 år, 40-59 år, 6o-79 år og 8o år og eldre). For de største sykdomsgruppene (hjerte- og karsykdommer, kreft, type 2-diabetes og kols) presenterer vi også resultater fordelt på menn og kvinner og i 20-årsaldersgrupper blant personer 40 år og eldre, fordi andelen med disse sykdommene er lav i aldersgruppen 20-39 år.

Andelen med hver sykdomstilstand blant covid-19-testpositive og innlagte er kjønns- og aldersjustert og presenteres med 95 \% konfidensintervall. For aldersjustering ble Rfunksjonen ageadjust.indirect fra R-pakken Epitools benyttet, med befolkningen i femårsaldersgrupper som referansebefolkning (므). Denne beregner også konfidensintervall.

\section{Resultater}

Befolkningen i alderen 20 år og eldre omfattet 4118 831 personer, hvorav $65 \%$ var 40 år og eldre. Videre var 8125 personer registrert som covid-19-testpositive i perioden 1.3.202013.5.2020 ifølge MSIS-registeret. 7632 (94\%) av disse var i alderen 20 år og eldre, og 5046 (66\%) var 40 år og eldre. I perioden fra januar til og med april 2020 hadde $1025(13,4 \%)$ av alle registrerte covid-19-testpositive i alderen 20 år og eldre vært innlagt på sykehus med covid-19, hvorav 905 (88\%) var 40 år og eldre. Gjennomsnittlig liggetid var åtte dager, median liggetid seks dager, mens høyeste liggetid var 50 dager.

Blant alle innlagte var 333 (18,3\%) registrert med hjerte- og karsykdom, 127 (6,9\%) med kreft, $150(8,6 \%)$ med type 2-diabetes og 67 (3,8 \%) med kols (andelene er kjønns- og aldersjustert). Dette var høyere enn i befolkningen (tabell 2).

Da vi så nærmere på de største sykdomsgruppene fordelt på kjønn og aldersgrupper fra fylte 40 år, så vi at andelen innlagte registrert med hjerte- og karsykdom, kreft, type 2diabetes og kols steg med økende alder (figur 1). Samme tendens så vi i befolkningen (figur 
1) og i gruppen covid-19-testpositive (data ikke vist). Blant covid-19-innlagte var det i flere aldersgrupper en høyere andel med de fire sykdomsgruppene enn i befolkningen både blant kvinner og menn (figur 1). Tallene er imidlertid små og har brede konfidensintervaller. Andelen innlagte registrert med én av disse sykdommene i aldersgruppen fra fylte 40 år, var 31,3\%, mens andelen med to var $16,9 \%$, tre var 2,8 \% og andelen med fire sykdommer var $0,4 \%$ (ikke aldersjustert). Det var små forskjeller mellom kvinner og menn, og andelen innlagte med flere sykdommer $ø$ kte med alderen (data ikke vist).

Befolkningen - Personerinnlagt med covid-19
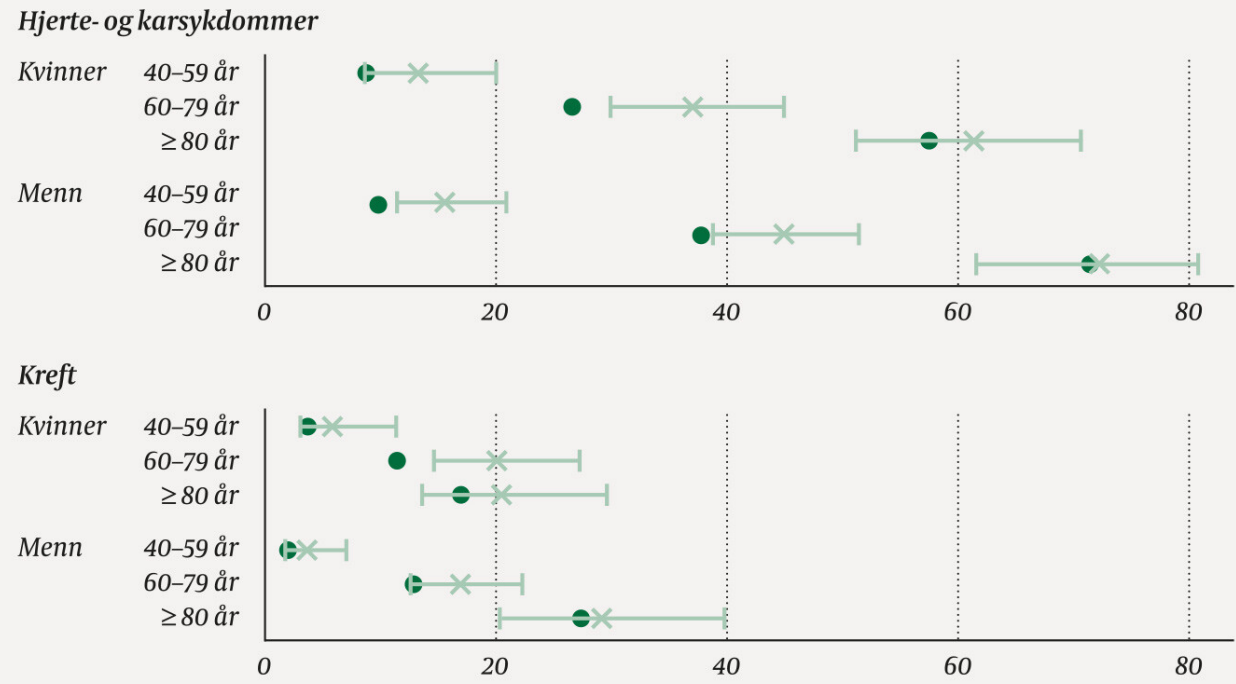

Diabetes type 2

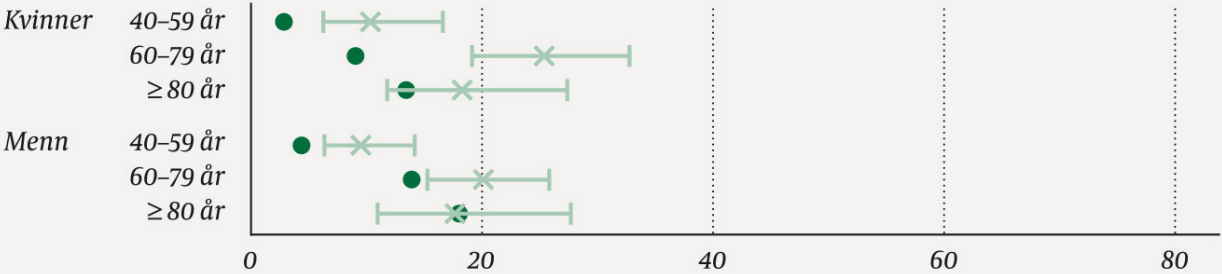

Kronisk obstruktiv lungesykdom

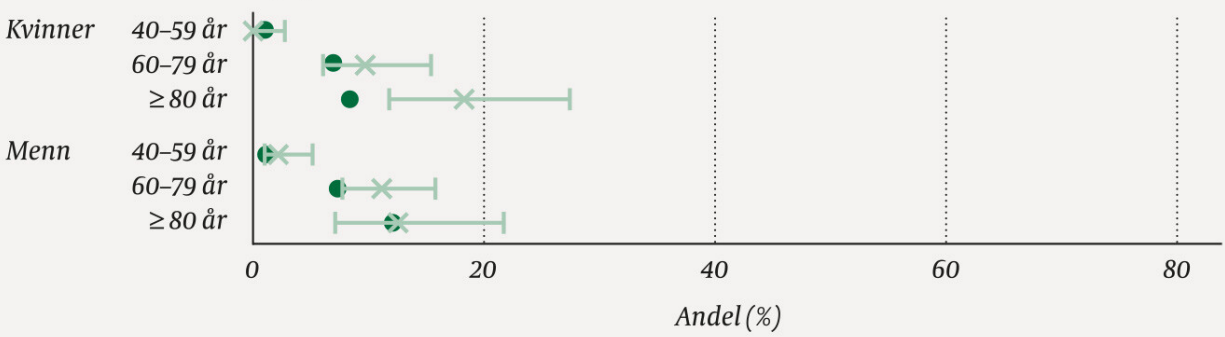

Figur 1 Andelen med hjerte- og karsykdom, kreft, diabetes type 2 og kronisk obstruktiv lungesykdom fra fylte 40 år i den totale befolkningen $(N=2676532)$ og blant covid-19innlagte $(\mathrm{N}=905)$, delt ut ifra kjønn og i 20 -årsaldersgrupper. Kryss = andelen blant covid19-innlagte vist med $95 \%$ konfidensintervall. Runde punkter $=$ andelen i befolkningen . Andelen med andre underliggende sykdommer og tilstander for begge kjønn samlet i alderen 20 år og eldre viser at gruppen covid-19-innlagte og testpositive fordeler seg over flere sykdomstilstander (tabell 2). Blant de innlagte er det flere personer registrert med behandlingsopphold for kreft de siste seks månedene og også de siste tre månedene, og flere personer med astma, annen kronisk lungesykdom, hjerte- og karsykdommer, hjertesvikt, komplikasjoner til hypertensjon, fedme, overvekt, nyresvikt og nevrologiske lidelser enn i befolkningen (tabell 2). 
Hvordan dette fordeler seg over aldersgrupper blant covid-19-innlagte er vist i figur 2-5. Blant de eldste er det flere innlagte med kreft under behandling de siste tre månedene enn i befolkningen (figur 2). I denne aldersgruppen er andelen covid-19-testpositive med demens høyere enn i befolkningen (data ikke vist), men ikke blant innlagte (figur 2). Videre ser vi at andelen med type 1-diabetes, astma, annen lungesykdom, kreft, hjertesvikt, fedme og nyresvikt er høyere enn i befolkningen i aldersgruppen 60-79 år (figur 3). I

aldersgruppen 40-59 år er andelen med type 2-diabetes, astma, atrieflimmer, hjerte- og nyresvikt, komplikasjoner til hypertensjon, overvekt, magesår og gallelidelser høyere enn i befolkningen (figur 4), mens andelen med astma, hjerte- og karsykdommer, hjerneslag og nevrologiske lidelser er høyere enn i befolkningen i aldersgruppen 20-39 år (figur 5). Vi vil bemerke at tallene er små, noe som reflekteres i konfidensintervallene.

Befolkningen - Personerinnlagt med covid-19

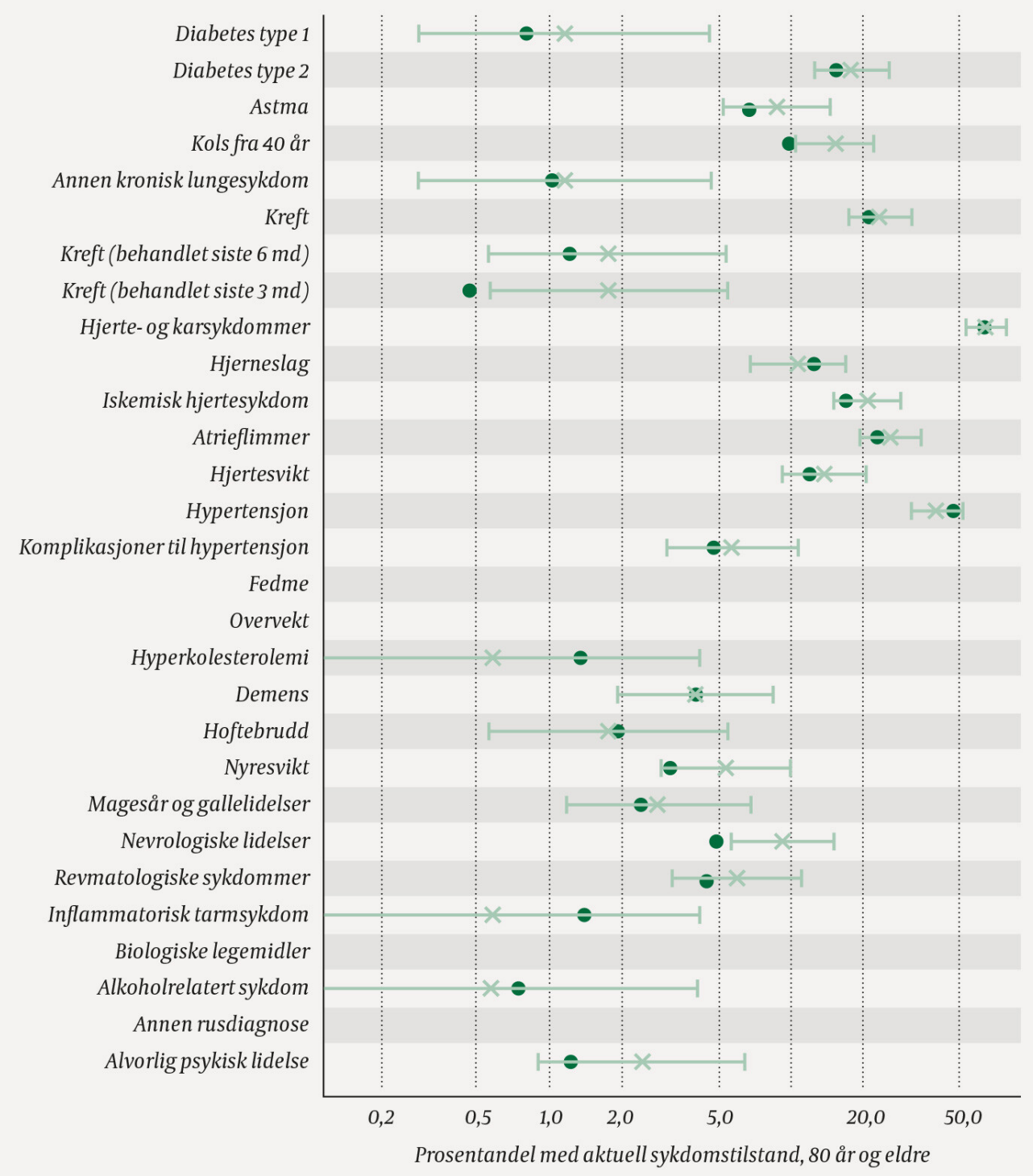

Figur 2 Andelen med de ulike sykdommene/tilstandene i aldersgruppen 80 år og eldre i befolkningen $(\mathrm{N}=230710)$ og blant covid-19-innlagte $(\mathrm{N}=172)$. Tilstander med andel $\geq 0,5 \%$ $\mathrm{i}$ befolkningen eller $>1 \%$ blant innlagte i den aktuelle aldersgruppen er vist. Kryss $=$ andelen blant covid-19-innlagte vist med 95\% konfidensintervall. Runde punkter $=$ andelen i befolkningen. Det er logaritmisk skala på x-aksen. 
Befolkningen - Personerinnlagt med covid-19

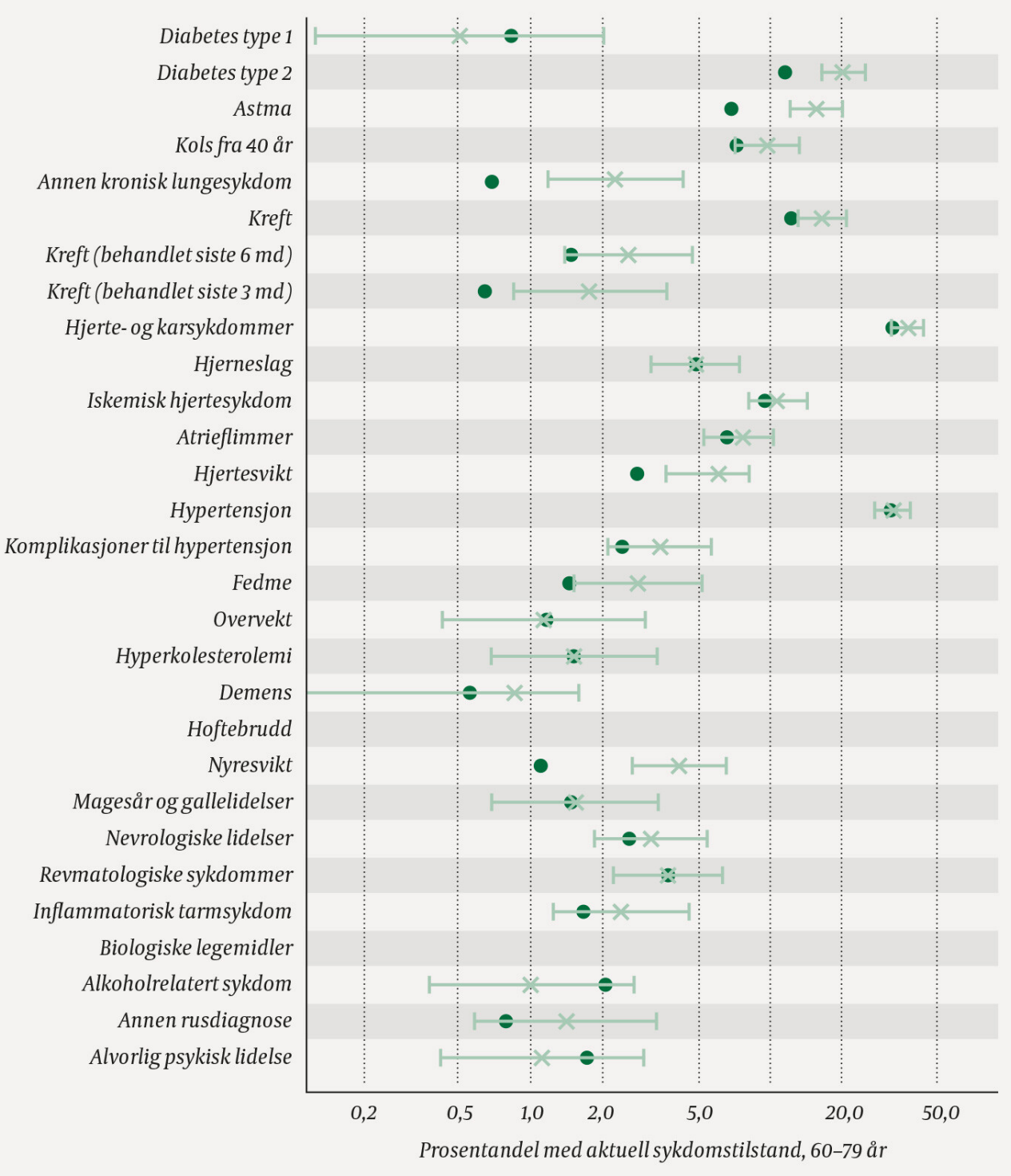

Figur 3 Andelen med de ulike sykdommene/tilstandene i aldersgruppen 6o-79 år i befolkningen ( $\mathrm{N}=1018329)$ og blant covid-19-innlagte $(\mathrm{N}=379)$. Tilstander med andel $\geq 0,5$ $\% \mathrm{i}$ befolkningen eller $>1 \%$ blant innlagte $\mathrm{i}$ den aktuelle aldersgruppen er vist. Kryss $=$ andelen blant covid-19-innlagte vist med $95 \%$ konfidensintervall. Runde punkter $=$ andelen i befolkningen. Det er logaritmisk skala på x-aksen. 
Befolkningen - Personerinnlagt med covid-19

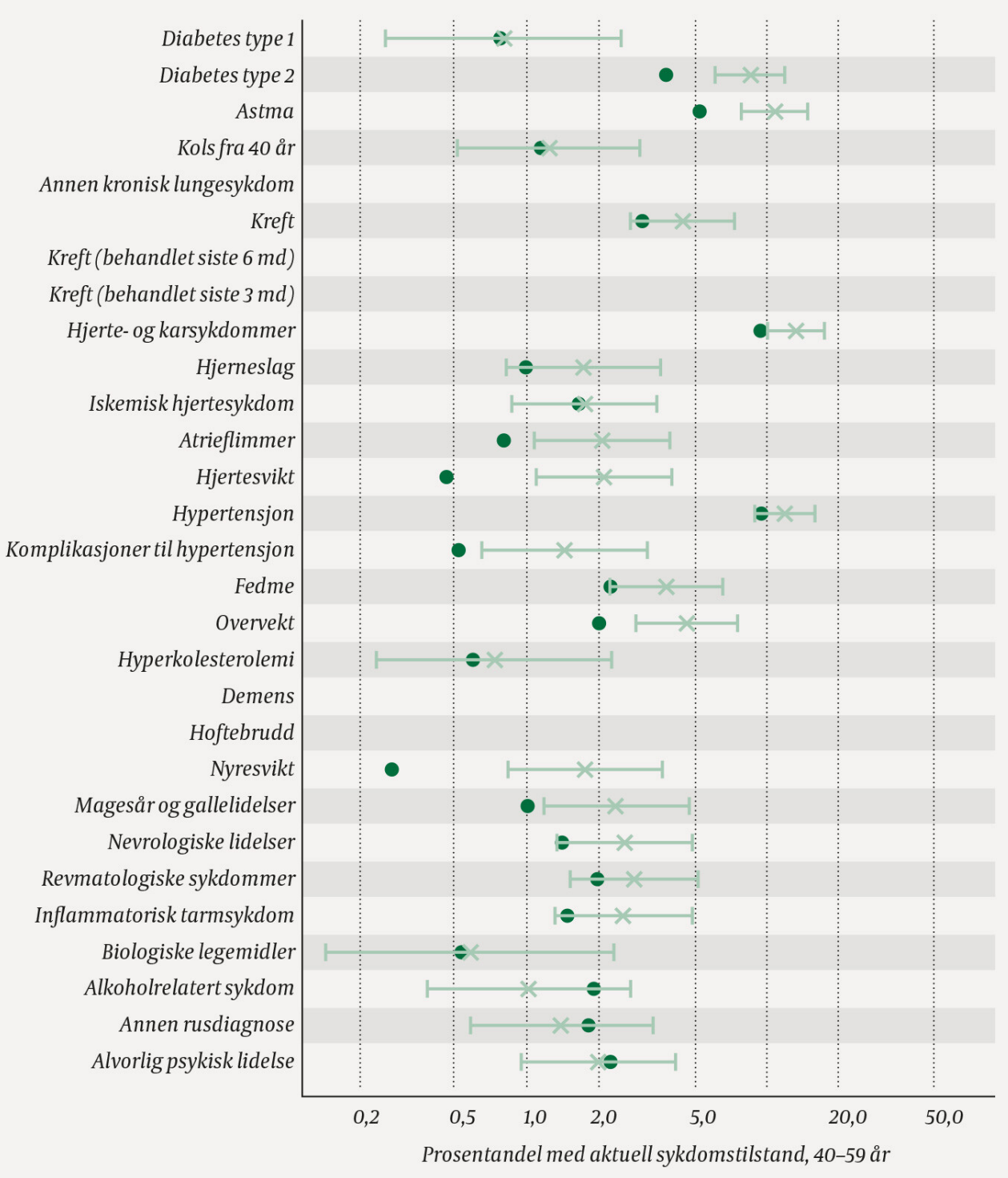

Figur 4 Andelen med de ulike sykdommene/tilstandene i aldersgruppen 40-59 år i befolkningen $(\mathrm{N}=1427493)$ og blant covid-19-innlagte $(\mathrm{N}=354)$. Tilstander med andel $\geq 0,5$ $\% \mathrm{i}$ befolkningen eller $>1 \%$ blant innlagte i den aktuelle aldersgruppen er vist. Kryss = andelen blant covid-19-innlagte vist med 95\% konfidensintervall. Runde punkter $=$ andelen i befolkningen. Det er logaritmisk skala på x-aksen. 
Befolkningen - Personerinnlagt med covid-19

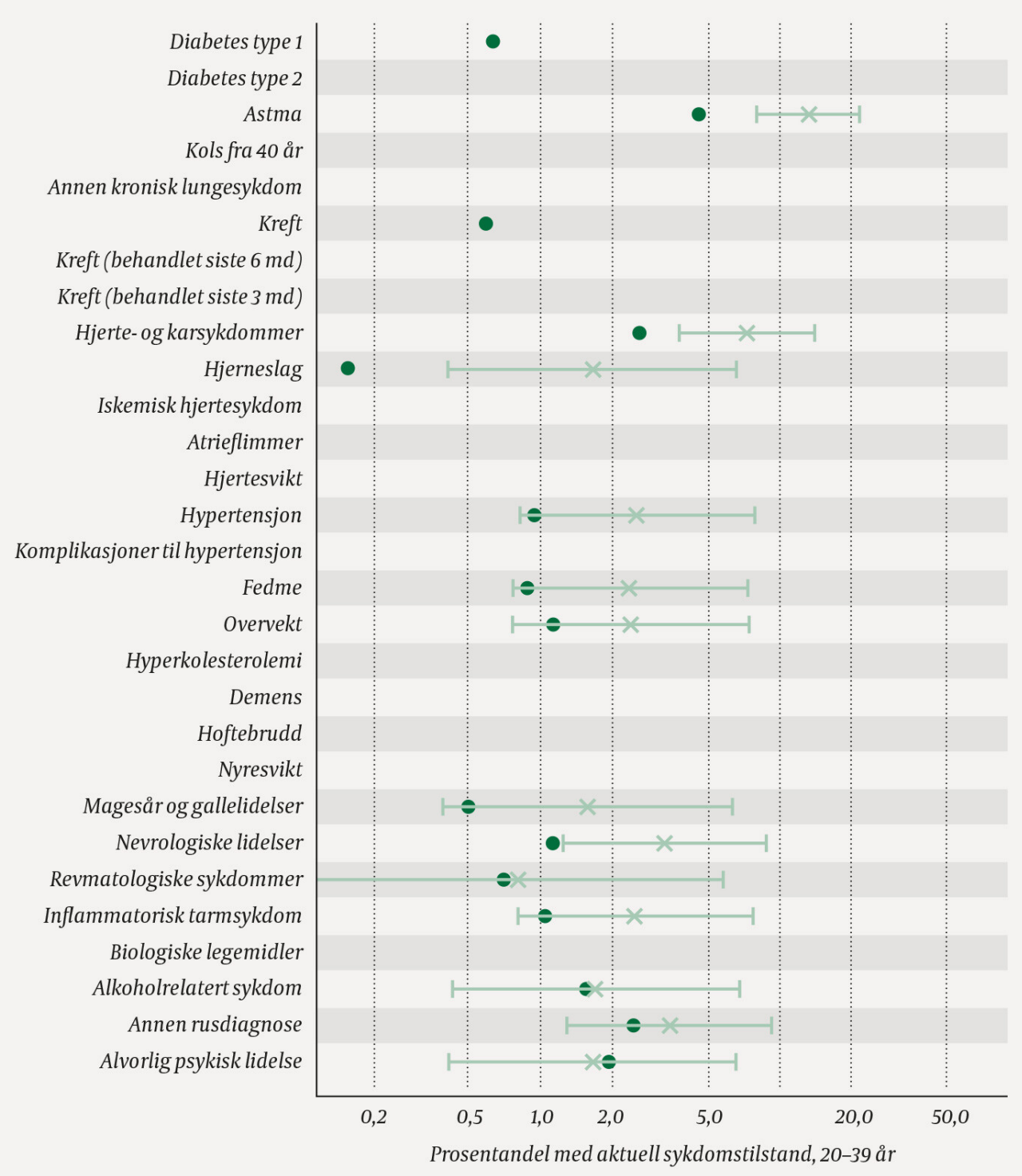

Figur 5 Andelen med de ulike sykdommene/tilstandene i aldersgruppen 20-39 år i befolkningen ( $\mathrm{N}=1442$ 299) og blant covid-19-innlagte $(\mathrm{N}=12 \mathrm{O})$. Tilstander med andel $\geq 0,5$ $\% \mathrm{i}$ befolkningen eller $>1 \%$ blant innlagte $\mathrm{i}$ den aktuelle aldersgruppen er vist. Kryss $=$ andelen blant covid-19-innlagte vist med 95\% konfidensintervall. Runde punkter $=$ andelen i befolkningen. Det er logaritmisk skala på x-aksen.

\section{Diskusjon}

Blant innlagte voksne registrert med covid-19 var det flere med ulike underliggende sykdomstilstander enn i befolkningen. Sykdomsbildet endret seg med alder. Vi fant en tendens til en høyere andel registrert med ikke-smittsomme sykdommer som hjerte- og karsykdommer, kreft, type 2-diabetes og kols enn i befolkningen i flere aldersgrupper både blant kvinner og menn. Det var liten forskjell i forekomst av registrerte tilstander mellom personer med en positiv test for covid-19 og befolkningen.

Det er foreløpig lite forskning som kan si noe sikkert om personer med spesifikke underliggende sykdommer og tilstander har $ø$ kt risiko for et alvorlig forløp ved covid-19 (7.). I de fleste studiene er analysene basert på grupper av befolkningen der det vil være en seleksjon både for å bli testet for SARS-CoV-2 og for å bli innlagt med covid-19 $(\underline{8}, 9$. .). Det har stor betydning for resultatene $(7, \underline{10})$. 
Høy alder alene, eller tilstedeværelse av flere sykdommer, er forbundet med alvorlig forløp av covid-19 (7.). Det er imidlertid vanskelig å avklare om $\emptyset$ kning i risiko for alvorlig forl $\emptyset p$ av covid-19 skyldes tilstedeværelse av ulike sykdommer eller om det reflekterer at personer med disse sykdommene og høy alder oftere blir innlagt for å være føre var.

Det er vanskelig å skille mellom disse forholdene også i vårt prosjekt. Det å bli innlagt på sykehus for covid-19 kan i seg selv være et uttrykk for alvorlighetsgrad. Vi ser imidlertid at selv om lengden på oppholdet kan si noe om alvorligheten av covid-19-infeksjonen, er det noen med svært kort opphold som døde under eller rett etter oppholdet. Det vil derfor være vanskelig å gradere alvorlighetsgrad blant innlagte ut fra lengden på oppholdet eller bruk av intensivbehandling alene.

Analyser av enkeltsykdommer har pekt på at hjerte- og karsykdom, kreft, diabetes og kols er overrepresentert blant personer som får alvorlig forløp av covid-19, selv om funnene ikke er helt entydige på tvers av studier (4.). I en studie fra Petrilli og medarbeidere er for eksempel ikke kroniske lungesykdommer overrepresentert blant innlagte (1ㅡ). For andre sykdommer, som for eksempel diabetes, samsvarer funnene noe mer på tvers av studier og med det vi finner. En dansk ikke-fagfellevurdert studie av Reilev og medarbeidere viser at andelen med diabetes er høyere blant voksne med et alvorlig forløp av covid-19 (10 $)$. Det er lite kunnskap om hvordan sykdomstilstandene fordeler seg på alder og kjønn blant innlagte sammenlignet med befolkningen. Våre data er derfor av verdi, selv om datamaterialet er lite og selektert og må tolkes med forsiktighet.

Andelen innlagte med flere ikke-smittsomme sykdommer som hjerte- karsykdom, kreft, type 2-diabetes og kols øker med alderen og kan forklare noe av aldersforskjellene. Det er interessant at vi blant de eldste, 80 år og eldre, finner at flere covid-19-testpositive enn i befolkningen er registrert med demens, mens andelen innlagte med demens ikke er høyere enn i befolkningen. Dette kan delvis skyldes de norske testrutinene, hvor personer med økt risiko, inkludert eldre med demens på sykehjem, hyppigere kan ha blitt testet, men kanskje ikke i like stor grad blitt innlagt.

Styrken med denne registerstudien er at den inkluderer hele den norske befolkningen fra fylte 20 år. Det betyr at vi har vist hvordan andelen av befolkningen med de store sykdomsgruppene hjerte- og karsykdommer, kreft, type 2-diabetes og kols fordeler seg på kjønn og alder blant covid-19-innlagte og covid-19-testpositive. Dette er viktig når vi skal vurdere mulige effekter av pandemier som kan ramme personer i disse store sykdomsgruppene. Vi inkluderte separate analyser for kreftpasienter som var i aktiv behandling, da man kan anta at de vil være mer sårbare enn andre kreftpasienter. Andelen med kreft under behandling blant covid-19 innlagte var også høyere enn i befolkningen.

En registerstudie vil inkludere data som ikke er validerte. Her gjelder ikke det for definisjonen av pasientgruppen, fordi en av styrkene i vår studie er at det er godt samsvar mellom MSIS-registeret og koding i Norsk pasientregister for innlagte pasienter. Når det gjelder alle de nevnte sykdomstilstandene, derimot, vil ikke-validerte data være inkludert. Validering av data fra Norsk pasientregister kan for eksempel vise at «mistanke om en sykdom» er kodet som "sykdommen». I tillegg vet vi ikke nok om datakvaliteten $\mathrm{i}$ Kommunalt pasient- og brukerregister, i og med at dette er et relativt nytt register. Overestimering av sykdomsforekomst er generelt sannsynlig i registerstudier uten validering, og det er en svakhet. Prosjektet har dessverre ikke data på multimorbiditet for alle sykdomstilstandene. Det betyr at en person kan være påvirket av mer enn én sykdom, på samme måte som i befolkningen de innlagte sammenlignes med.

Oppfølgingstiden for de ulike registrene varierer. Norsk pasientregister har informasjon om avsluttede opphold, og vi har dermed ikke data om dem som var inneliggende over månedsskiftet april/mai. Det ville ha styrket studien om vi også hadde tilgang til data om inneliggende pasienter. Det er sannsynlig at det blant disse var en andel som hadde lang liggetid og mer alvorlig forløp. Det er imidlertid grunn til å anta at denne svakheten i studien ikke påvirker resultatene i særlig grad, siden gruppen er liten. Koden for covid-19- 
infeksjon skal etter regelverket ikke benyttes som hoveddiagnose. Det er i sykehusdataene derfor ikke mulig å skille mellom pasienter innlagt for covid-19 og pasienter som har fått påvist covid-19 under innleggelse for andre tilstander.

På grunn av de norske teststrategiene våren 2020 er sannsynligheten for å bli testet for covid-19 større for en person med en underliggende sykdomstilstand enn for en ellers frisk person med samme symptomer. Dersom mange har hatt covid-19 uten å bli testet, kan det svekke funnene i vår studie. Da vil de fleste av disse trolig være i gruppen «ellers friske», og man ville ha forventet en overrepresentasjon av kronisk syke blant de testpositive. Det ser imidlertid ikke ut som dette er tilfelle.

Dersom vi hadde hatt data om dem som testet negativt for covid-19, kunne vi anslått graden av seleksjon forårsaket av teststrategiene. At mange av dem som først fikk påvist covid-19 var spreke skiturister, kan også ha bidratt til å redusere andelen kronisk syke blant de testpositive. Trolig kan også en person med en underliggende sykdomstilstand legges inn med mildere symptomer enn en ellers frisk person. Vi vet at sannsynligheten for å bli lagt inn på sykehus under influensapandemien forårsaket av A(H1 N1)-viruset i 2009-2010 var høyere blant personer med type 2-diabetes enn i den generelle befolkningen, mens

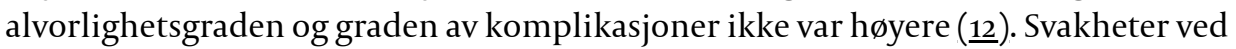
observasjonsstudier som benytter selektert datamateriale som i deler av denne studien, og hvordan det påvirker resultatene, er blant annet belyst i flere nylig publiserte artikler $(\underline{8}, .9$.), (13).

Hensikten med denne studien var å beskrive hvordan ulike sykdomstilstander fordelte seg blant personer med påvist covid-19 og blant innlagte med covid-19 sammenlignet med tilsvarende tall for befolkningen. Hovedformålet har vært overvåking og beredskap. Slik oversikt er viktig for å følge utviklingen i Norge videre. En registerkobling med persondata som også inkluderer alle som er testet for covid-19, og der gruppen covid-19-testpositive ikke er selektert, kunne ha bidratt til å besvare problemstillinger om risikoen for å bli smittet av eller innlagt for covid-19 og gitt mer kunnskap om underliggende årsaker til alvorlig sykdomsforløp.

Artikkelen erfagfellevurdert.

\section{LITTERATUR}

1. Emami A, Javanmardi F, Pirbonyeh $\mathrm{N}$ et al. Prevalence of underlying diseases in hospitalized patients with COVID-19: A systematic review and meta-analysis. Arch Acad Emerg Med 2020; 8: e35. [PubMed]

2. Folkehelseinstituttet. Råd og informasjon til risikogrupper og pårørende. https://www.fhi.no/nettpub/coronavirus/fakta/risikogrupper/ Lest 5.6.2020.

3. The Novel Coronavirus Pneumonia Emergency Response Epidemiology Team. The epidemiological characteristics of an outbreak of 2019 novel coronavirus diseases (COVID-19) - China, 2020. China CDC Weekly 2020; 2: 113-22. [CrossRef]

4. Brurberg K. COVID-19: The relationship between age, comorbidity and disease severity - a rapid review, $1^{\text {st }}$ update. Oslo: Folkehelseinstituttet, 2020.

https://www.fhi.no/globalassets/dokumenterfiler/rapporter/2020/covid-19-the-relationship-betweenage-comorbidity-and-disease-severity-1st-update-report-2020-v2-.pdf Lest 1.9.2O2O.

5. Bakken IJ, Ariansen AMS, Knudsen GP et al. The Norwegian Patient Registry and the Norwegian Registry for Primary Health Care: Research potential of two nationwide health-care registries. Scand J Public Health 2020; 48: 49-55. [PubMed][CrossRef]

6. The R Project for Statistical Computing. https://www.R-project.org/ Lest 1.9.2020.

7. Flodgren G, Vestrheim D, Brurberg K. COVID-19 and risk factors for severe disease - a rapid review, 2nd update. Oslo: Folkehelseinstituttet, 2020. https://www.fhi.no/en/publ/202o/COVID19-and-riskfactors-for-severe-disease-2nd-update/ Lest 28.5.2020.

8. Griffith G, Morris TT, Tudball M et al. Collider bias undermines out understanding of COVID-19 disease risk and undermines our understandingo f COVID-19 disease risk and severity medRxiv 2020 
doi: 10.1101/2020.05.04.20090506. [CrossRef]

9. Westreich D, van Smeden M, Edwards J. Response to Goldacre et al. (OpenSAFELY Collaborative). https://zenodo.org/record/3855586\#.X1CtQXkzaJM Lest 1.9.2020.

10. Reilev M, Kristensen KB, Pottegaard A et al. Characteristics and predictors of hospitalization and death in the first 9,519 cases with a positive RT-PCR test for SARS-CoV-2 in Denmark: A natiowide cohort. medRxiv 2020 doi: 10.1101/2020.05.24.20111823. [CrossRef]

11. Petrilli CM, Jones SA, Yang J et al. Factors associated with hospital admission and critical illness among 5279 people with coronavirus disease 2019 in New York City: prospective cohort study. BMJ 2020;369: m1966. [PubMed][CrossRef]

12. Ruiz PLD, Bakken IJ, Håberg SE et al. Higher frequency of hospitalization but lower relative mortality for pandemic influenza in people with type 2 diabetes. J Intern Med 2020; 287: 78-86. [PubMed][CrossRef]

13. Wynants L, Van Calster B, Collins GS et al. Prediction models for diagnosis and prognosis of covid19 infection: systematic review and critical appraisal. BMJ 2020;369: m1328. [PubMed][CrossRef]

Publisert: 16. september 2020. Tidsskr Nor Legeforen. DOI: 10.4045/tidsskr.20.0512

Mottatt 9.6.2020, første revisjon innsendt 4.7.2020, godkjent 1.9.2020.

Publisert under åpen tilgang CC BY-ND. Lastet ned fra tidsskriftet.no 26. april 2023. 